\title{
Science Teaching: It's Effect on the Performance of Fourth Year High School Students in Science Component of the System Admission and Scholarship Examination
}

\author{
Malano Macalabo Tingara-an \\ College of Arts and Trades \\ Mindanao State University, Marawi City, Philippines \\ malanotingaraan@gmail.com
}

\begin{abstract}
This study determined the effects of science teaching and learning factors on the performance of fourth year high school students in the science component of the Mindanao State University - System Admission and Scholarship Examination (MSU-SASE). These factors were grouped into namely: the learning environment factors, cognitive abilities in mathematics, reading comprehension, science vocabulary and mental ability; teacher variables such as teaching practices, teacher attitudes and teaching efficiency. It also included factors such as physical and laboratory facilities and administrative support. Three null hypotheses were tested using correlation statistics on the data obtained for the variables. The first two hypotheses drawn to show relationship between the student performance in the science component of the SASE with learning environment factors and different cognitive abilities were accepted whereas the hypothesis drawn for the teacher variables is rejected. Other findings showed that the physical and laboratory facilities are very poor and administrative support is very negligible. On the whole, the study is indicative of the state of science instruction of the MSU-Lanao National College of Arts and Trades which needs serious consideration and attention of the teachers and administrators.
\end{abstract}

Keywords: Learning environment and cognitive abilities

\section{INTRODUCTION}

Bernardt, Distino, Kamil and Munoz (1995) content that Science achievement is associated with the student's ability to understand specialized vocabulary well as specialized meaning of common words and even language proficiency. likewise Torres and Zeidley (2002) also emphasized that language proficiency is related to science content knowledge. Moreover, Cocking and Chipman (1992), MacGregor and Price (1998) had shown that language proficiency plays a vital role is mathematics achievement.

The results of their study showed that language ability is associated with learning algebra. Student's ability to express and understand language, according to Moschkovich (2000), are the key aspects of learning in both mathematics and science. He claimed that when a student learns, his achievement is to be expected. Fraser (1986) supported that the achievement of the students is higher when the preferred and perceived learning environment match.

Blooms (1996) included that no matter how excellent students' mental abilities, once the teachers behaviors and support of administration failed, the student will find difficulty in learning thus resulting in poor performance. This study were tested the following null hypothesis:

$\mathrm{H} \emptyset_{1}$ : There is no significant relationship between the performance of fourth year high school students in science component of SASE with learning environment factors.

$\mathrm{H}_{2}$ : There is no significant relationship between the performance of fourth year high school students and the following cognitive abilities:
a. Mental ability
b. Science vocabulary
c. Mathematics ability
d. Reading comprehension ability

$\mathrm{H}_{3}$ : There is no significant relationship between the performances of fourth year high chool students in the science component of SASE with:

a. Teacher's attitude toward science

b. Teacher's efficiency rating.

\section{METHODS}

This study involved both descriptive/qualitative and correlational method of investigation. The descriptive/qualitative designs were used to describe and establish the nature and degree of existing conditions through the profit of the respondents on the independent variables learning environment, cognitive abilities such as their abilities in mathematics, reading comprehension, science vocabulary, mental and the dependent variables, performance is the science component of the SASE.

Qualitative description of the variables and support factors were also used. The correlational design was adapted in establishing the relationship between the independent variables mentioned earlier and the dependent variable, performance in the science component of the SASE. In analyzing the data the following statistical were used: Pearson Product moment coefficient of correlations determines the relationship between the performance of the fourth year high school students in science component of the SASE with the learning environment and cognitive abilities. Mann Whitney U Test determined the correlation between the performance of the fourth year high school students in science component of the SASE and the teachers attitude and efficiency rating.

\section{RESULTS}

Table 1,2, and 3 is the results of research data analysis. 
Table 1

Correlation of SASE Science Performance and Learning Environment Factors.

\begin{tabular}{|l|l|l|l|l|}
\hline \multicolumn{1}{|c|}{ Learning Environment Factors } & \multicolumn{1}{c|}{ Mean } & \multicolumn{1}{c|}{ rxy values } & Sig (1 tai1) & \\
\hline SASE Science Score & 39.5327 & 1.000 & & \\
\hline Cohesiveness & 15.8411 & -0.101 & 0.150 & Not Significant \\
\hline Satisfaction & 14.3925 & -0.156 & 0.054 & Not Significant \\
\hline Organization & 13.3925 & 0.162 & 0.048 & Not Significant \\
\hline Affinity & 14.2710 & 0.082 & 0.199 & Not Significant \\
\hline Lesson & 19.4579 & -0.019 & 0.134 & Not Significant \\
\hline Competitiveness & 16.2336 & -0.108 & 0.289 & Not Significant \\
\hline Physical Environment & 32.5327 & -0.110 & 0.291 & Not Significant \\
\hline Teacher & 7.1042 & 0.054 & -0.165 & 0.068 \\
\hline Over-all LES & 17.9812 & & Not Significant \\
\hline
\end{tabular}

Table 2

Pearson-Product Moment Correlation (rxy) Values between SASE Science Component and Cognitive Abilities

\begin{tabular}{|l|l|l|l|l|l|}
\hline \multicolumn{1}{|c|}{ Cognitive Abilities } & \multicolumn{1}{|c|}{ Mean } & \multicolumn{1}{c|}{ Rxy values } & P-values & Decision \\
\hline SASE Science Score & 7.104 & 1.0000 & & \\
\hline Mental Ability & 8.350 & 0.068 & 0.480 & Not Significant \\
\hline Reading Comprehension & 5.870 & 0.138 & 0.152 & Not Significant \\
\hline Mathematics Ability & 12.97 & 0.025 & 0.796 & Not Significant \\
\hline Science Vocabulary Ability & 31.67 & 0.053 & 0.585 & Not Significant \\
\hline
\end{tabular}

Table 3

Student Science Performance and Teacher Variables

\begin{tabular}{|l|l|l|l|}
\hline \multicolumn{1}{|c|}{ Variables } & $\begin{array}{c}\text { Mann-Whitney u- } \\
\text { value }\end{array}$ & P value & Decision \\
\hline Science Performance & & 0.000 & \\
\hline Teacher's Attitude & 86.5 & 0.000 & Significant \\
\hline Teacher's Efficiency Rating & & 0.000 & Significant \\
\hline
\end{tabular}

\section{DISCUSSION}

One of the major problems of a school system is the students' poor academic performance in certain subjects especially science (Glasser, 1969). Poor academic student performance has a powerful impact on students school administrators, and parents as performance may indicate the strength of teachinglearning process in the classroom.

For example, poor performance of Filipino students' participation in the Second International Science Study (SISS) and Third International Mathematics and Science Study (TIMSS) implies the weakness of science and mathematics education of our country (Ibe and Ogena, 2001).

This is one of the biggest challenges that the education section of our government faces today. Both the policy-makers and stakeholders are looking forward to resolve these problems. This is one reason why Department of Science and Technology (DOST) and the Department of Education (DepEd) have priority projects like the Mindanao Upgrading of Science Teachers (MUST) and the Rescue Initiative in Science Education (RISE) and other training programs are given empetus with the intention to upgrade teaching competencies in Science and Mathematics.

The government also strongly supports the DepEd in implementing the Restructured Basic Education Curriculum (RBEC), with the hope that the quality of instruction and students' performance in Science, Mathematics, English and Filipinos will improve. The Al-Ghamdi, a review program has been instituted in the university in the hope to improve the passing rate students graduating from the external high school. Lanao National College of Arts and Trades, formerly a CHED-supervised institution is now integrated in MSU System is not exempted of having its graduating high school students take the SASE.

Its performance is also monitored also by university. In the monitoring done, it has been found that in the 4 consecutive results (2001-2006) of the SASE (MSU Admission Office), the performance of the examinees from MSU-LNCAT High School is still poor in comparison with other external unit high schools. For this reason perhaps it is necessary to conduct a study that can identify the problems behind this consistently poor student performance, in the hope that solutions may be suggested to the LNCAT administration to improve student performance.

\section{CONCLUSION}

The relationship between the performance of fourth year students in the science component of SASE and the learning environment factor is not significant. The null hypothesis is accepted at $\mathrm{P}=0.05$. The relationship between the performance of the students and the cognitive abilities namely, mental ability, reading comprehension, mathematics ability and science vocabulary ability are not significant.

The relationship between the teacher variables such as teachers attitude towards science and teaching efficiency rating are significant. The null hypothesis tested has been rejected at $\mathrm{P}=0.05$. There is very inadequate in terms of financial allocations for library references and consumables. 


\section{REFERENCES}

[1] Bernhardt, E., Destino, T., Kamil., and Munoz, M., 1995. Assessing Science knowledge in and English and Spanish Bilingual Elementary School. Cognoss.

[2] Blooms, B. S. 1996. Learning for Mastery. In Bloom, B. S. (Ed)., Formative \& Summative Education of Student Learning. New York: McGraw-Hill.

[3] Cocking, R., and Chipman, S. 1982. Conceptual Issues Related to Mathematics Achievement of Language Minority Children. Hillsdale, NJ: Lawrence Ertdum.

[4] Fraser, B. J. 1986. Research on Classroom \& School Climate. Melbourne, Australia: Australian Council for Educational Research.

[5] Glasser, W. 1969. Schools' Without Failure. New York: Harper and Row.

[6] McGregor, M., \& Price, E. 1998. An Exploration of Aspects of Language Proficiency and Algebra Learning. Journal for Research in Mathematics Education, 30(4), 449-467.

[7] Moschkovich, J. N. 2000. Learning Mathematics in Two Language: Moving from Obstacles to Resources. In W. G. S. (Ed). Changing the Faces of Mathematics Perspective on Multicultural and Gender Equity (pp.85-93). Reston, VA: NCFM.

[8] Torres, H. N., \& Zeidler, D. L. 2002. The Effect of Language Proficiency and Reasoning Skills in the Acquisition of Science Content Knowledge by Hispanic English Language Learners and native English Language Speaking Students. Electronic Journal of Science Education, 6(3). 